\title{
Development and validation of a flax (Linum usitatissimum L.) gene expression oligo microarray
}

\author{
Stéphane Fenart ${ }^{1}$, Yves-Placide Assoumou Ndong ${ }^{2}$, Jorge Duarte ${ }^{3}$, Nathalie Rivière ${ }^{3}$, Jeroen Wilmer ${ }^{4}$, \\ Olivier van Wuytswinkel ${ }^{2}$, Anca Lucau' ${ }^{1}$ Emmanuelle Cariou', Godfrey Neutelings ${ }^{1}$, Laurent Gutierrez ${ }^{6}$, \\ Brigitte Chabbert ${ }^{7}$, Xavier Guillot ${ }^{8}$, Reynald Tavernier ${ }^{9}$, Simon Hawkins', Brigitte Thomasset ${ }^{10^{*}}$
}

\begin{abstract}
Background: Flax (Linum usitatissimum L.) has been cultivated for around 9,000 years and is therefore one of the oldest cultivated species. Today, flax is still grown for its oil (oil-flax or linseed cultivars) and its cellulose-rich fibres (fibre-flax cultivars) used for high-value linen garments and composite materials. Despite the wide industrial use of flax-derived products, and our actual understanding of the regulation of both wood fibre production and oil biosynthesis more information must be acquired in both domains. Recent advances in genomics are now providing opportunities to improve our fundamental knowledge of these complex processes. In this paper we report the development and validation of a high-density oligo microarray platform dedicated to gene expression analyses in flax.
\end{abstract}

Results: Nine different RNA samples obtained from flax inner- and outer-stems, seeds, leaves and roots were used to generate a collection of 1,066,481 ESTs by massive parallel pyrosequencing. Sequences were assembled into 59,626 unigenes and 48,021 sequences were selected for oligo design and high-density microarray (Nimblegen 385K) fabrication with eight, non-overlapping 25-mers oligos per unigene. 18 independent experiments were used to evaluate the hybridization quality, precision, specificity and accuracy and all results confirmed the high technical quality of our microarray platform. Cross-validation of microarray data was carried out using quantitative qRT-PCR. Nine target genes were selected on the basis of microarray results and reflected the whole range of fold change (both up-regulated and down-regulated genes in different samples). A statistically significant positive correlation was obtained comparing expression levels for each target gene across all biological replicates both in qRT-PCR and microarray results. Further experiments illustrated the capacity of our arrays to detect differential gene expression in a variety of flax tissues as well as between two contrasted flax varieties.

Conclusion: All results suggest that our high-density flax oligo-microarray platform can be used as a very sensitive tool for analyzing gene expression in a large variety of tissues as well as in different cultivars. Moreover, this highly reliable platform can also be used for the quantification of mRNA transcriptional profiling in different flax tissues.

\section{Background}

Flax (Linum usitatissimum L.) has long been cultivated by man for its cellulose-rich bast fibres and seeds [1,2]. The long bast fibres are traditionally used in the textile industry for the production of linen or mixed fibre textiles, and, together with shorter xylem fibres are also used in the automobile and construction industries $[3,4]$. Flax seeds are widely integrated into animal feeds

\footnotetext{
* Correspondence: brigitte.thomasset@utc.fr

${ }^{10}$ UMR CNRS 6022, GEC, Université de Technologie de Compiègne, BP 20529, 60205 Compiègne cedex, France

Full list of author information is available at the end of the article
}

[5] and are also important in human health since they are a major source of omega-3 fatty acids [6] and biologically active lignan [7]. Linseed oil from seeds is equally used in the fabrication of paint, lacquer and varnish, soap, putty and polymers $[8,9]$.

In order to breed improved flax varieties we need to increase our fundamental knowledge of flax biology (fibre and seed formation, disease resistance, growth etc.) since many important questions remain unanswered. For example, although we know that fibre quality is related to the extremely low lignin levels found in this cell type as compared to wood fibres, we do not

\section{Biomed Central}


know how lignin biosynthesis is regulated in flax fibres [10]. Similarly, although the different biosynthetic pathways involved in fatty acid production in linseed are known, we still know relatively little about the biological mechanisms controlling linolenic acid levels in traditional flax varieties (45-65\% omega-3 fatty acid) compared to solin or linola varieties $(2 \%)[11,12]$.

The size of the flax genome (686 Mbp) is around four times that of Arabidopsis and recently different research teams have developed reverse genetics and genomic approaches to learn more about fibre and seed formation in this economicly-important species [13-18]. A cDNA custom flax array system has recently been constructed and successfully used to characterize genes expression profiles in fibre-bearing stem tissues $[17,18]$. This platform was constructed by spotting 9,600 anonymous cDNA clones obtained from a flax stem-peel cDNA library. In this paper we report the development and validation of a flax-specific high-density oligomicroarray platform using Nimblegen technology. Flax cDNAs generated from different tissues and/or developmental stages from two different flax cultivars (oil-seed and fibre flax respectively) were 454-sequenced and assembled into contigs. These contigs representing genes found in both oil-seed and fibre flax were used to produce a $48 \mathrm{~K}$ array. The high quality of our array was demonstrated by the high reproducibility of different technical replications, as well as by the platform's capacity to identify differential gene expression profiles in different tissues and flax varieties.

\section{Results and discussion}

\section{Sequencing and contig assembly}

In order to produce representative high-density flax (Linum usitatissinum) microarrays, we extracted RNA from 9 different samples (Table 1) corresponding to different tissues and/or developmental stages from two flax cultivars (Barbara, an oil-seed cultivar, and Hermes, a

Table 1 Details of flax samples used for GS FLX sequencing and for microarray validation experiments

\begin{tabular}{|c|c|c|c|c|}
\hline \multirow{2}{*}{$\begin{array}{c}\begin{array}{c}\text { Roots } \\
\text { (Hermes) }\end{array} \\
(\mathbf{R})\end{array}$} & \multirow{2}{*}{$\begin{array}{c}\begin{array}{c}\text { Leaves } \\
\text { (Hermes) }\end{array} \\
(\mathbf{L})\end{array}$} & \multicolumn{2}{|c|}{$\begin{array}{c}\text { Stems } \\
\text { (Hermes) }\end{array}$} & \multirow{2}{*}{$\begin{array}{c}\begin{array}{c}\text { Seeds } \\
\text { (Barbara) }\end{array} \\
10-15 \\
\text { DAF } \\
\text { (S1) }\end{array}$} \\
\hline & & Outer tissue & Inner tissue & \\
\hline & & $\begin{array}{c}\text { Vegetative phase } \\
\text { (SOV) }\end{array}$ & $\begin{array}{c}\text { Vegetative phase } \\
\text { (SIV) }\end{array}$ & $\begin{array}{l}20-30 \\
\text { DAF } \\
\text { (S2) }\end{array}$ \\
\hline & & $\begin{array}{c}\text { Green capsule } \\
\text { phase } \\
\text { (SOGC) }\end{array}$ & $\begin{array}{c}\text { Green capsule } \\
\text { phase } \\
\text { (SIGC) }\end{array}$ & $\begin{array}{l}40-50 \\
\text { DAF } \\
\text { (S3) }\end{array}$ \\
\hline
\end{tabular}

$\mathrm{R}=$ roots; $\mathrm{L}=$ leaves; $\mathrm{SOV}$ = stem outer tissues; vegetative stage; $\mathrm{SIV}=$ stem inner tissues; vegetative stage; SOGC = stem outer tissues, green capsule stage; SIGC = stem inner tissues, green capsule stage; $\mathrm{S} 1$ = seeds, 10-15 Days After Flowering (DAF); S2 = seeds, 20-30 DAF, S3 = seeds, 40-50 DAF. fibre cultivar) and prepared them for 454 sequencing. Different samples were chosen for their biological interest e.g. young- (10-15 Days After Flowering, DAF), midstage- (20-30 DAF) and maturing- (40-50 DAF) seeds correspond to early, maximal and late stages of storage compounds synthesis. Similarly, vegetative growth (50-60 days after germination, DAG) and green capsule stages (70-80 DAG) are associated with fibre development.

Four 454 GSFLX half-runs were used to sequence the 9 samples generating 1,068,375 reads with an average length of $281 \mathrm{bp}$ and a total of $287 \mathrm{Mb}$ (Table 2). MIDs (Multiplex identifiers) were used to mix samples into the same half-runs: SOV/SOGC, SIV/SIGC, L/R, and $\mathrm{S} 1 / \mathrm{S} 2 / \mathrm{S} 3$. Individual sample data was then separated from the four SFF (Standard Flowgram Format) files using the Roche 454 SFF info tool.

After cleaning 881,950 reads were assembled into 59,494 contigs, with 132 singlets giving a total of 59,626 unigenes http://urgi.versailles.inra.fr/index.php/urgi/ Species/Flax/Dowload-sequences. The N50 was 569 bp and 17,487 contigs were longer than $500 \mathrm{bp}$. 17,731 contigs had only 2 reads, $>15,000$ contigs contained more than 10 reads and $>8,500$ contigs contained more than 20 reads. The number of reads varied from 1 to more than 3,500 potentially reflecting the relative abundance of the different transcripts. Incorporation of Sanger sequences available in the public domain did not alter our assembly suggesting that the shorter reads generated by 454 sequencing did not represent a problem for correct assembly (data not shown).

\section{Functional Characterization, GO notation}

Contigs were loaded into the EST2uni database and the corresponding pipeline was used to make all annotations. BLAST analyses were used to compare flax contig sequences to 4 different databases (TAIRV7_cds, TAIRV7_pep, EMBL_plant and UNIPROT_plant; Table 3). Between $21.3 \%$ and $62.9 \%$ contigs show significant

Table 2454 GS FLX sequencing data for the 9 samples

\begin{tabular}{ccccc}
\hline $\begin{array}{c}\text { Tissues/ } \\
\text { Samples }\end{array}$ & Reads \# & $\begin{array}{c}\text { Average } \\
\text { length }\end{array}$ & Bases \# & $\begin{array}{c}\text { Bases after } \\
\text { clip \# }\end{array}$ \\
\hline SOV & 162,256 & 289.62 & $43,779,333$ & $33,153,393$ \\
\hline SOGC & 112,872 & 275.58 & $30,082,124$ & $23,827,193$ \\
\hline SIV & 133,816 & 294.61 & $35,475,882$ & $27,206,866$ \\
\hline SIGC & 154,790 & 299.80 & $41,108,455$ & $31,266,452$ \\
\hline L & 134,342 & 286.15 & $36,243,207$ & $26,340,221$ \\
\hline R & 131,051 & 273.08 & $35,614,353$ & $24,190,625$ \\
\hline S1 & 76,232 & 259.95 & $20,913,548$ & $14,693,725$ \\
\hline S2 & 80,148 & 252.54 & $22,077,809$ & $14,419,155$ \\
\hline S3 & 82,868 & 272.14 & $22,203,052$ & $16,630,053$ \\
\hline All & $\mathbf{1 , 0 6 8 , 3 7 5}$ & $\mathbf{2 8 1 . 6 7}$ & $\mathbf{2 8 7 , 4 9 7 , 7 6 3}$ & $\mathbf{2 1 1 , 7 2 7 , 6 8 3}$ \\
\hline
\end{tabular}


Table 3 Numbers and percentages of flax unigenes showing blast hits against different databases

\begin{tabular}{lcc}
\hline Database & Number of flax unigene hits & $\%$ \\
\hline TAIRV7_cds & 12672 & 21.3 \\
\hline TAIRV7_pep & 32399 & 54.3 \\
\hline EMBL_plant & 22804 & 38.2 \\
\hline UNIPROT_plant & 34473 & 57.8 \\
\hline Any database & 37490 & 62.9 \\
\hline
\end{tabular}

similarity to known genes (evalue $\leq \mathrm{e}-20$ ), depending upon the database used for comparison and putative Arabidopsis orthologs were found for $14.7 \%$ flax contigs. The relatively low value is probably to be expected since the reciprocal blasts necessary to identify putative orthologs was performed between the non-redundant Arabidopsis gene data set and the $59 \mathrm{~K}$ flax unigene set. GO annotations could be assigned to approximately $25 \%$ of the unigenes by similarity using blast results and GOA and TAIR gene cross-referenced files. 10,010 sequences (16.8\%) could be assigned molecular functions (Figure 1A), 14,501 sequences (24.3\%) could be assigned biological processes (Figure 1B) and 16,570 sequences $(27.8 \%)$ sequences could be assigned cellular components (Figure 1C).

\section{Microarray Design}

Analyses of the $59 \mathrm{~K}$ unigene set allowed for several different probe design possibilities. After examination, we chose a design based upon $48 \mathrm{~K}$ contigs as being the most representative of the $59 \mathrm{~K}$ unigene set. Microarrays were designed according to the Roche/Nimblegen protocol based on 3' end cDNA synthesis and both annotated and non-annotated contigs were used. The final design contained 8 non-overlapping oligos (25-30 mers) per contig allowing for both qualitative and quantitative hybridization. This design is available at the GEO web site http://www.ncbi.nlm.nih.gov/projects/geo/ under the platform number GPL104.

\section{Parameters of microarray performance}

The Nimblegen array system is based upon the hybridization of a single labeled sample (derived from RNA), followed by one-channel detection. The intensity of the hybridization signal is then used to determine target concentration. In order to check the technical quality of each probe in our flax Nimblegen arrays, we performed 18 independent hybridizations on nine samples representing different tissues and/or different developmental stages (Table 1) with two technical repetitions. In order to avoid any potential bias due to biological variability the hybridizations were performed on the same RNA samples (Table 1) used for 454 sequencing. Technical quality was determined by evaluating the following parameters: hybridization quality, precision and accuracy.

\section{Hybridization quality}

Our results (GEO GSE21868) showed that all probes present on the array were capable of hybridizing successfully (signal > background) when tested on the different samples. The sensitivity of the array was demonstrated by the wide signal dynamic range obtained ( $\log 2$ values of 4 to 16). The experimental metrics report (NimbleScan v2.5) was used as recommended by Roche/Nimblegen to generate summary statistics that can be used to identify any potential problems during hybridization. Most of these metrics (interquartile density, signal range, uniformity mean, uniformity CV (coefficient of variation), number of empty features on the array, mean empty, the number of random control features present on the array, mean Random) assume probe randomization on the array surface. Thus, deviation from uniformity (i.e. outside the recommended value range) across the array could suggest potential artifacts during hybridization. Metric values (data not shown) for all 18 samples analyzed were within the recommended value range indicating that hybridization quality was satisfactory.

\section{Precision}

A crucial aspect of all microarray experiments is good system reproducibility enabling direct and reliable comparisons between different experiments. Precision describes how accurately the hybridization signal intensity can be reproduced and is usually reported as a correlation coefficient, standard deviation or average replicate error between duplicated experiments using the same RNA sample [19]. Raw expression data on the $18(9 \times 2)$ flax hybridization experiments were normalized and Pearson's correlation coefficients were calculated for the data sets of hybridization signal intensities. High correlation coefficients were obtained in all cases and the results obtained for the flax leaf sample are shown in Figure 2. These results $(r \geq 0.98 ; \mathrm{p}$-value $<$ $2.2 \mathrm{e}^{-16}$ ) indicate an almost perfect correlation between different technical experiments underlining the extremely high precision level for our flax oligo-array platform. Such reproducibility is similar to that obtained with Affymetrix GeneChips [20] and is probably also due to probe redundancy. Previous work has shown that the use of multiple independent oligonucleotides designed to hybridize to different regions of the same RNA improves signal-to-noise ratio and the dynamic range of detection, as well as minimizing cross-hybridization effects [21].

\section{Accuracy}

Accuracy describes how close to a true value a measurement lies. It can be estimated in experiments where a number of realistic targets are spiked at known concentrations into relevant RNA populations, or from 


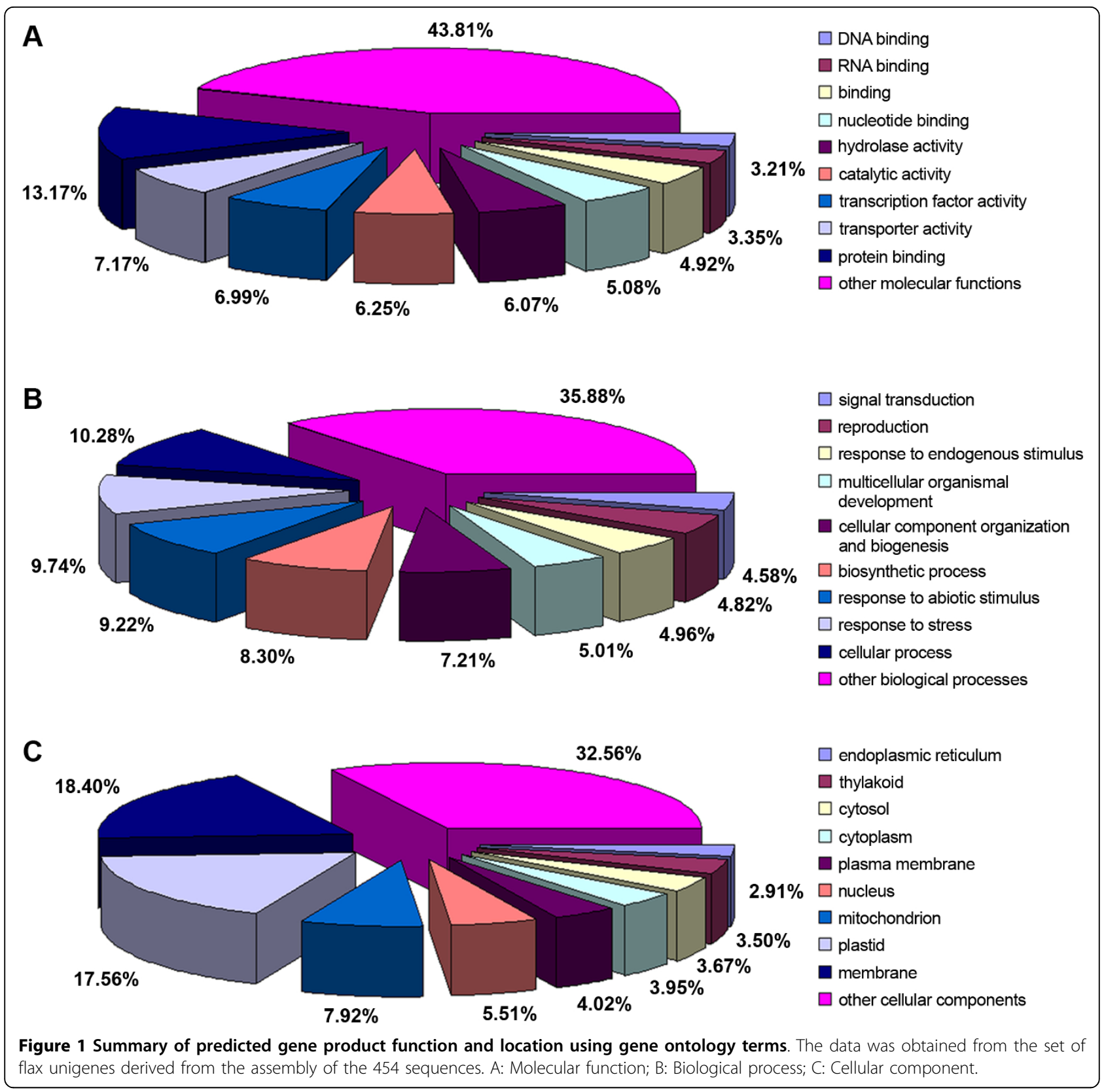

comparisons with validation experiments, or by correlation of two different methods [19].

Gene-specific quantitative qRT-PCR was used for the cross-validation of platform performance and as an assessment of microarray accuracy. We selected 9 genes reflecting up-regulated (c20715, c2491 c602), downregulated (c2533, c3323, c4370) or equally-expressed genes (c21991, c24118, c9380) in leaf (L) samples compared with stem (SIGC) samples. Selected genes also covered a wide range of signal intensity (5.384914.0473). Table 4 shows the expression levels of the same target genes detected by qRT-PCR and microarray analyses. Expression level was calculated as log2ratio of mean signal intensity across three technical replicates between L and SIGC samples. A statistically significant correlation $\left(\mathrm{r}=0.9823, \mathrm{p}=2.376 \mathrm{e}^{-06}\right)$ between $\mathrm{qRT}$ PCR and microarray results was obtained for all tested genes (Figure 3) indicating high concordance between these 2 data sets. The observation that the fold-change values in gene expression are lower for the microarray data as compared to the qRT-PCR data is most likely due to data compression resulting from limited dynamic range or signal saturation [22]. These data indicate that our oligo-array platform is able to accurately predict the 


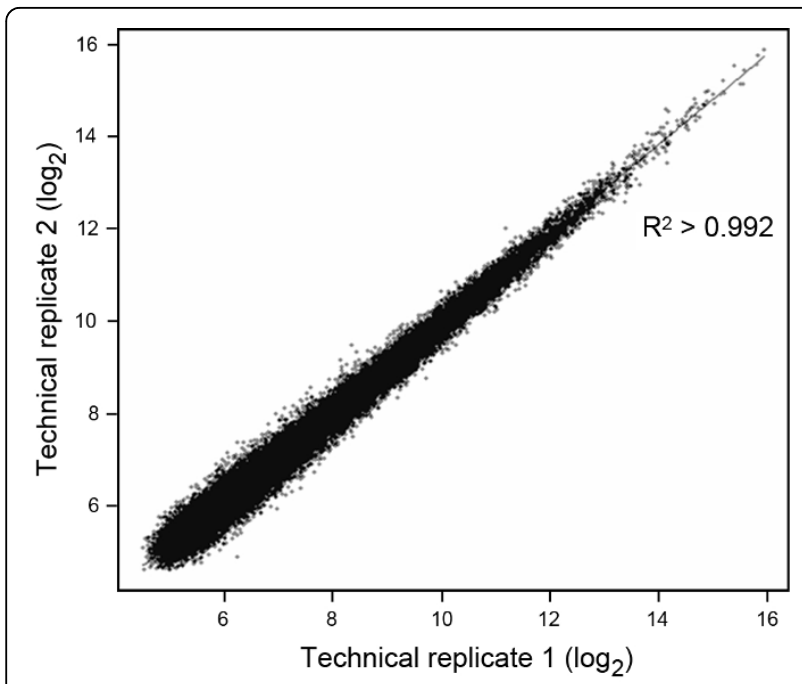

Figure 2 Microarray reproducibility. Scatter plot showing correlation between 2 microarray technical replicates (example shown on flax leaf sample, L). High correlations were found between all technical replicates $\left(r=0.98\right.$ or higher, $\mathrm{p}$-value $\left.<2.2 \mathrm{e}^{-16}\right)$.

direction of change of gene expression level (i.e. either up or down regulation) between subsets of interest.

\section{Differential gene expression detection}

In order to see whether our flax microarray platform was able to generate biologically-useful information, we analyzed its capacity to detect specific gene expression profiles associated with different tissues, different developmental stages, and different genotypes. Firstly, we used principal component analysis (PCA) to compare expression profiles in the 9 different samples previously hybridized. Secondly, we compared the expression of 4 genes known to be involved in the process of secondary cell wall biosynthesis and wood formation. Thirdly, we directly compared expression profiles between inner and

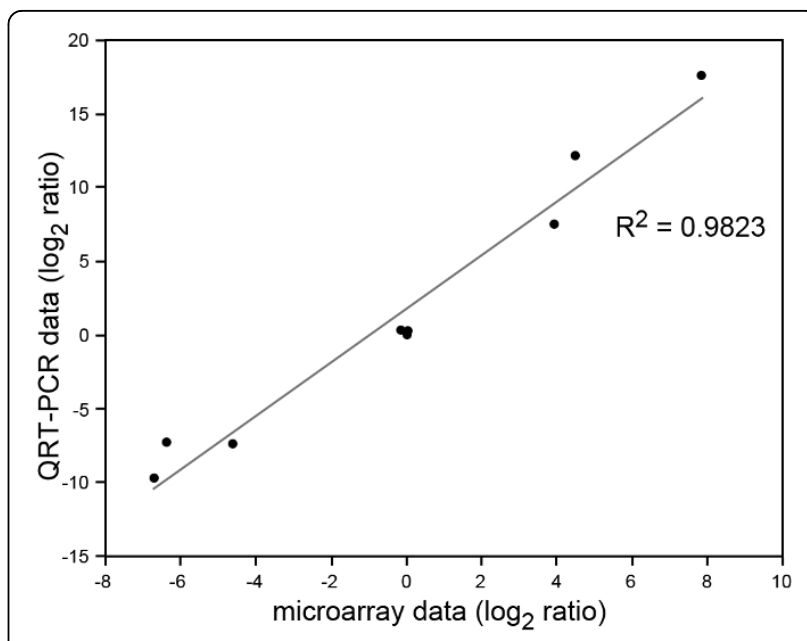

Figure 3 Correlation between qRT-PCR and microarray results. A statistically significant correlation $\left(r=0.9823, p=2.376 e^{-06}\right)$ was obtained for all tested genes.

outer stem tissues at two developmental stages. Finally, we compared gene expression profiles in 2 supplementary flax varieties that show differences in fibre quality and disease resistance.

\section{Differential gene expression in flax tissues and developmental stages}

The results of principal component analysis (PCA) of microarray data and representative $\mathrm{K}$-means profiles of tissue-/stage-specific gene expressions are shown in Figure 4. Three major regions of dispersion are found: A) genes specifically expressed in roots (Figure 4, top, profile 1), B) genes expressed specifically in stems and leaves (Figure 4, left, profiles 2-4) and C) genes specifically expressed in seeds (Figure 4, right, profiles 5-7). Genes similarly expressed in all tissues are clustered in the middle of the figure.

J-Express generated a list of 1,357 specifically expressed genes of which 609 were root-specific genes,

Table 4 Comparison of expression levels (log2ratio) from qRT-PCR and microarray for selected target genes

\begin{tabular}{|c|c|c|c|}
\hline Target Transcript & Gene ID & $\begin{array}{l}\text { Microarray value } \\
\text { (Log2ratio) }\end{array}$ & $\begin{array}{l}\text { qRT-PCR value } \\
\text { (Log2ratio) }\end{array}$ \\
\hline Lipoxygenase LOX2 & c20715 & 7.86465 & 17.6 \\
\hline Chlorophyll $a-b$ binding protein $3 C$-like & C2491 & 3.9446 & 7.47 \\
\hline RuBisCO activase 2 & c602 & 4.5263 & 12.185 \\
\hline DNA-directed RNA polymerase II & c21991 & 0.01865 & -0.015 \\
\hline Calmodulin TaCaM2-1 & c24118 & -0.10225 & 0.295 \\
\hline Ubiquitin carboxyl- terminal hydrolase & C9380 & 0.05875 & 0.215 \\
\hline Cellulose synthase & c2533 & -4.5911 & -7.37 \\
\hline Laccase & c3323 & -6.3722 & -7.31 \\
\hline Fasciclin-like AGP 4 & c2370 & -6.7035 & -9.72 \\
\hline
\end{tabular}

Gene expression was calculated as log2ratio of L vs SIGC samples, using mean signal intensity across three technical replicates of each sample. Values $>1$ indicate up-regulation, and values $<-1$ indicate down-regulation. 


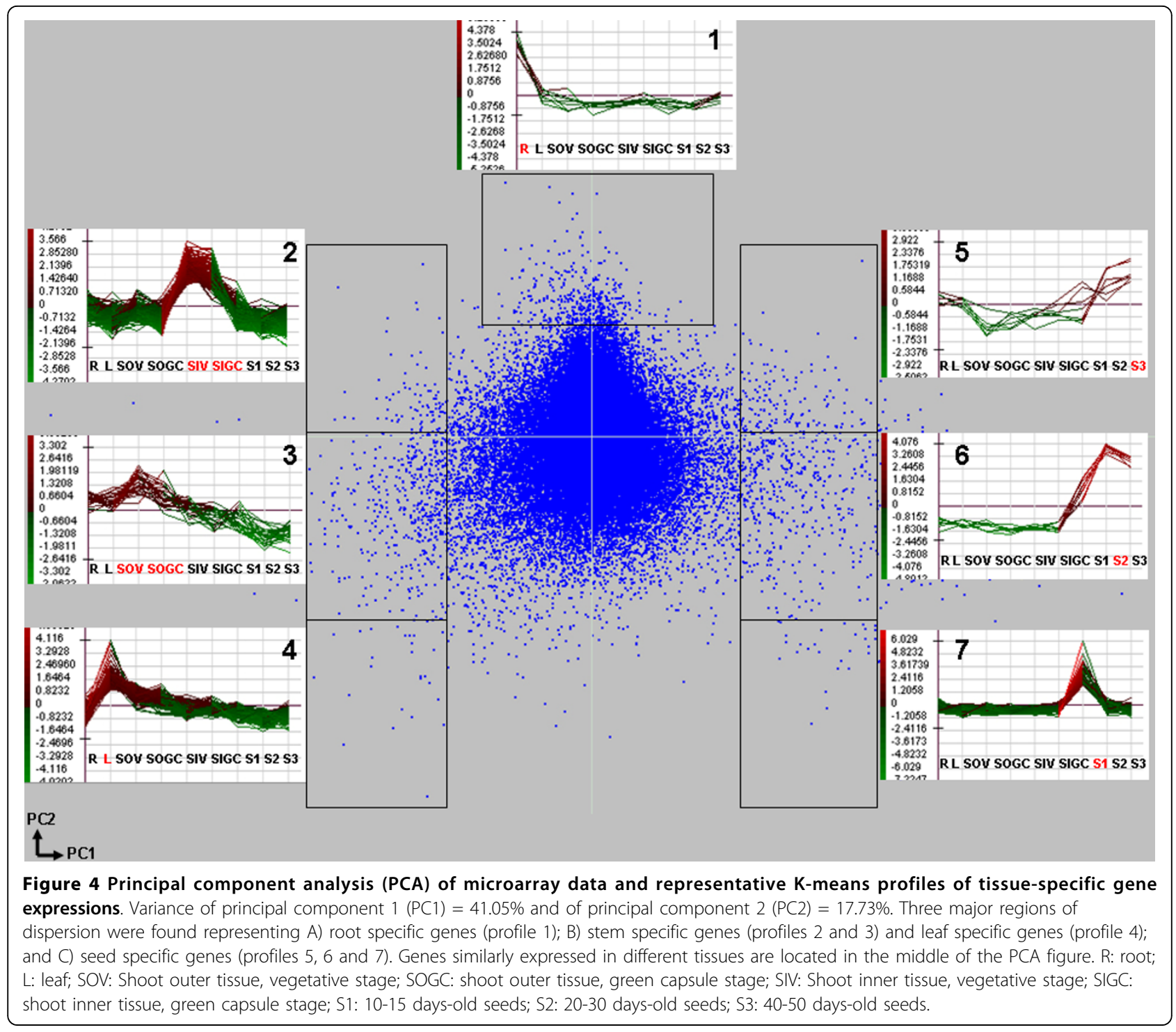

599 leaf-specific genes, 79 shoot-specific genes and 70 seed-specific genes. Differential expression profiles of these genes were verified by a SAM test with a FDR less than 5\%. Annotated genes in these different groups were then classified into different GO biological processes and the percentages of tissue-specific gene expressions were calculated for each process (Figure 5A).

Overall, these results are in general agreement with the known physiological processes of the different organs/tissues thereby suggesting that our platform is capable of generating biologically-useful gene-expression data. For example, leaves are well known to be the plant's main photosynthetic organs and leaf structure is closely associated with its photosynthetic function and chloroplast biogenesis [23-31]. The observation that the GO process 'photosynthesis' is entirely composed of genes specifically expressed in the leaves (Figure 5A), as are the GO processes 'cellular component biogenesis', and 'protein modification process' is in agreement with the biological structure and role of this organ. In root tissues the GO processes 'cell growth' and 'response to stress' were the most represented functions in agreement with the biological activities of this organ [32,33]. As in other plant species, the flax stem is characterized by the differentiation of different specialized tissues $[18,34]$ and the majority stem-specific gene expression in the development GO process is in keeping with the biological activity of this organ. Finally, cell-cycle and cellular homeostasis GO processes were associated with embryo-specific gene expressions characteristic of embryogenesis [35].

Similar analyses (Figure 5B) of the relationship between different tissue-specific genes and metabolisms also suggest that our platform is capable of generating 


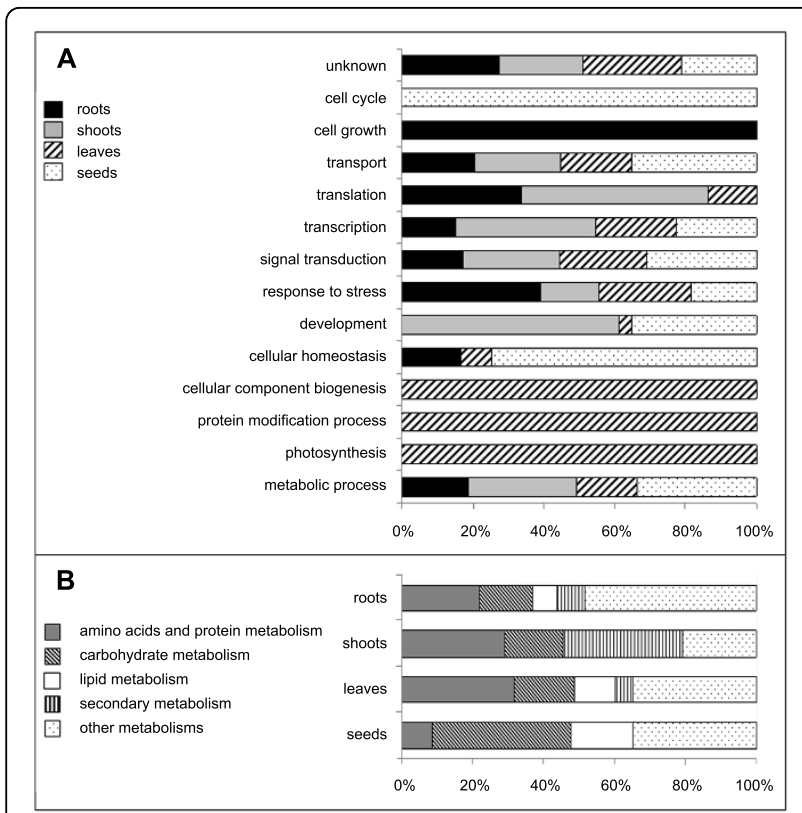

Figure 5 GO unigene annotation on microarray data. A Percentage representation of differentially expressed genes from different flax tissues in different GO biological processes. B -

Percentage representation of differentially expressed genes from different flax tissues in different metabolisms.

biologically-relevant information. Of interest are the relatively high percentages of genes associated with lipid and carbohydrate metabolisms in seeds since direct quantitative measurements [36] have shown that sucrose and lipids represent the largest metabolite pools in flax seeds. Similarly, secondary metabolism represents the major metabolism in flax stems and is most likely associated with the lignification of xylem secondary cell walls [34].

\section{Differential gene expression in a targeted process}

We compared the expression of four genes known to be involved in the process of secondary cell wall biosynthesis and wood formation characteristic of inner stem tissues [37]. Expression levels of cellulose synthase (c2533), phenylalanine ammonia-lyase (c247), transcinnamate 4-hydroxylase (c11079), and caffeoyl-CoA 3-O-methyltransferase (c15771) were calculated as $\log 2$ ratio of the signal intensity in each tissue $v s$. the average of signal intensity across all analyzed tissues (Figure 6). As expected, the great majority of these genes were more highly expressed in inner tissues (at both developmental stages examined). These observations confirm that the flax oligo-array platform is able to accurately discriminate gene expression profiles in different tissues.

\section{Differential gene expression between flax inner and outer} stem tissues

In order to verify that our oligo-array platform could be used in future studies to provide biologically-relevant information about cell wall formation and fibre development in flax, we compared expression profiles between the heavily lignified inner stem tissues and the outer stem tissues enriched in weakly-lignified bast fibres at two different developmental stages.

The results (Additional files 1 and 2) showed that in vegetative stage samples, 203 genes were over-expressed in inner stem tissues as compared to outer stem tissues (cut-off: $\log 2$ ratio $(\mathrm{SIV} / \mathrm{SOV})>2$ ), and 229 genes were over-expressed in outer stem tissues as compared to inner stem tissues. Examination of the 203 genes overexpressed in the inner stem tissues showed that 56 genes $(28 \%)$ were potentially associated with cell wall formation and xylem identity. Of these differentiallyexpressed cell wall genes, 50\% (28 genes) were associated with lignification and included both monolignol biosynthetic genes and laccases involved in the oxidative polymerisation of this phenolic polymer. Such an observation is in agreement with the fact that flax inner stem tissues, mainly composed of xylem, are much more heavily lignified than the outer tissues containing cellulose-rich bast fibes [34]. Other cell-wall related genes coded for proteins involved in polysaccharide cell wall polymer synthesis and remodelling. In addition, 3 genes (C1109, C3396, C5556) coding for fasciclin-like arabinogalactan proteins (FLAs) were also over-expressed in inner tissues as compared to outer tissues. Interestingly, FLA genes are highly expressed in flax outer stem tissues, as well as in poplar tension wood where they have been hypothesized to be involved in the formation of cellulose-rich gelatinous fibres (g-fibres) $[17,37,38]$. Our observation (see below) that 3 other FLA genes (C2947, C3576, C5237) are more highly expressed in flax outer stem tissues when compared to inner stem tissues could suggest that these proteins play a role in secondary cell wall formation in both flax inner and outer stem tissues.

Similar analyses (Additional files 1 and 2) of the 229 genes over-expressed in flax outer stem tissues when compared to inner stem tissues revealed that only 16 genes $(7 \%)$ were associated with cell wall formation. In contrast, 25 genes were potentially associated with lipid and wax metabolism, 8 genes were related to photosynthesis and 8 genes were stress-related. These differences reflect the different physiological status of flax inner and outer stem tissues. For example, the high percentage of 'cell-wall-related' transcripts in inner stem tissues is associated with secondary xylem formation while the relative abundance of photosynthesis-related transcripts reflects the fact that outer stem tissues are green. Nevertheless, it is interesting to note that 6 genes (C1423, C6325, C353, C1410, C8886, C5052) overexpressed in outer stem tissues corresponded to Lipid Transfer Proteins (LTPs). LTPs have been previously associated with diverse aspects of cell wall development 


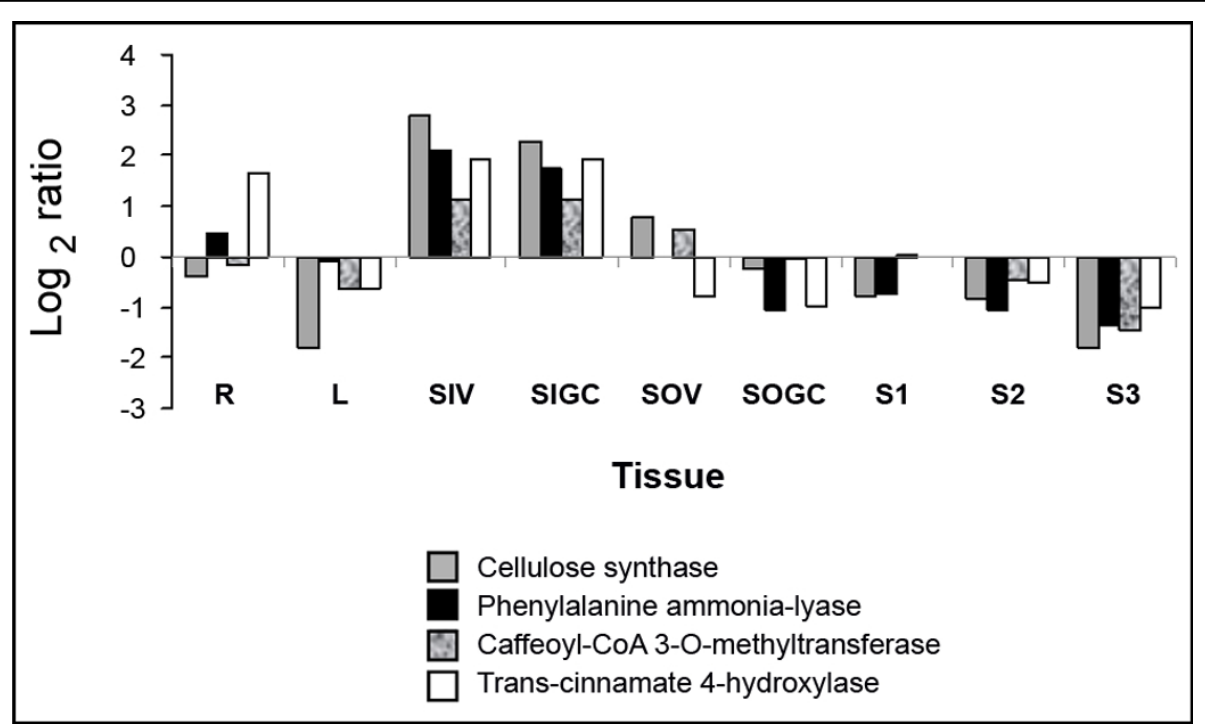

Figure 6 Expression levels of $\mathbf{4}$ genes involved in secondary cell wall biosynthesis and wood formation. Gene expression was calculated as log2ratio of the signal intensity in each tissue vs. The average of signal intensity across all analyzed tissues.

and formation and have also been shown to be more highly expressed in flax outer stem tissues [17,39]. Such an observation could suggest that such proteins might be associated with fibre maturation in flax. As indicated above, 3 FLAs (C2947, C3576, C5237) were also overexpressed in outer stem tissues as compared to inner stem tissues.

Comparison (Additional files 1 and 2) of inner and outer stem tissue expression profiles (cell-wall related genes) at the green capsule stage revealed a very similar differential expression pattern to that observed for the vegetative stage suggesting that little modification/evolution of inner and outer stem transcriptomes occurs between these two developmental stages. This was confirmed by the observation that only 3 cell-wall related genes (C25634, C2733, C11945) were up-regulated in inner stem tissues at the vegetative stage as compared to the green capsule stage, and no cell-wall related genes were up-regulated in inner stem tissues at the green capsule stage as compared to vegetative inner stem tissues. In outer stem tissues, 8 cell wall genes (C31544, C37539, C6312, C59350, C6820, C44241, C5939, C51183) were more highly expressed at the vegetative stage as compared to the green capsule stage. Two of these genes (C44241, C5939) code for xyloglucan endotransglycosylase/hydroalses (XTHs), one gene (C6820) codes for a secondary cell wall associated glycosyltransferase and one gene for a FLA. Since these 4 genes are implicated in cell wall remodelling and assembly events, such an observation could suggest that cell wall formation in outer stem tissues is more active at the vegetative stage as compared to the green capsule stage. No cell wall genes were more highly expressed at the green capsule stage as compared to the vegetative stage.

The vegetative stage (7-8 weeks) corresponds to the fast-growth stage associated with the increase in plant height and fibre lengthening above the snap point, as well as fibre cell wall thickening below the snap point [40]. At the green capsule stage (10-11 weeks) fibres have stopped elongating and further fibre development is restricted to continued fibre cell wall thickening [40,41]. Our results would suggest that continued fibre thickening (as well as continued secondary xylem formation in flax inner stem tissues) is associated with continued expression of cell wall related genes.

Altogether these analyses confirm that our oligo-array platform represents a powerful tool for investigating cell wall development and fibre formation in flax stems. Our arrays should also prove extremely useful for investigating other interesting biological processes in flax such as oil and seed formation, disease resistance and tolerance to abiotic stress.

\section{Differential gene expression in contrasting flax genotypes}

We used our platform to see whether the flax microarrays were able to detect differentially-expressed genes between 2 contrasting flax genotypes - Drakkar and Belinka. Drakkar produces better quality fibres than the variety Belinka, as well as being more resistant to the fungal pathogen Fusarium http://www.lin-itl.com[42]. RNA was isolated at the green capsule stage from outer stem tissues of field-grown flax plants and 3 biological and 2 technical repetitions were used for each variety. Following hybridization, the Log2ratio was calculated as the intensity signal of each gene in the Drakkar genotype $v s$. 
Belinka. The Pearson's correlation was $>0.99$ for technical repetitions and $>0.97$ for biological repetitions for both Belinka and Drakkar. A total of 428 up-regulated genes and 367 down-regulated genes were found. Only 269 genes were annotated or associated with a known biological function. (Additional files 3 and 4).

Since the 2 genotypes show differences in fibre quality and pathogen resistance, we focused our attention on those differentially-expressed genes associated with cell wall biosynthesis and response to biotic stimuli. Fibre quality in flax is associated with both the structure of the cellulose-rich secondary cell wall and the architecture (length, diameter) of individual fibres [16,34,43]. The observation (Figure 7A) that 10 cell-wall related genes were up-regulated in Drakkar, as compared to Belinka is therefore extremely interesting. These genes include 1 gene (cellulose synthase catalytic subunit c1532) involved in cellulose biosynthesis, 3 genes (xylose synthase - c59577; secondary cell wall-related glycosyltransferase family 47 - c9188; secondary wall-associated glycosyltransferase family $8 D$ - c7526) involved in secondary cell wall hemicellulose synthesis, 3 genes (phenylalanine amonnia lyase - c59528; caffeic acid omethyltransferase - c629; coniferyl alcohol 9-O-methyltransferase (c26370), involved in phenylpropanoid/lignin biosynthesis, 1 gene (xyloglucan endo-transglycosylase c5939) involved in cell wall expansion, 1 gene (cell wall apoplastic invertase - c7453) involved in sucrose partitioning [44], and 1 gene (fasciclin-like AGP 2 - c51183) that has previously been associated with both flax fibre formation [45] and G-fibre formation in tree reaction wood $[46,47]$. Only 1 cell wall related gene (xyloglucan endotransglucosylase hydrolase - c33660) associated with wall remodeling events was up-regulated in Belinka as compared with Drakkar. The up-regulation of these genes could suggest that cell wall biosynthesis is more dynamic in the Drakkar variety and is possibly related to the different fibre quality characteristic of this variety. However, further functional validation is obviously necessary before confirming such hypotheses.

A total of 14 genes involved in biotic stress response were up-regulated in Drakkar as compared with Belinka,

\begin{tabular}{|c|c|c|c|c|}
\hline \multirow{12}{*}{$\mathbf{A}$} & Gene ID & log2ratio & Gene DB & Gene description \\
\hline & genolin_c59528 & 1.5600 & Q6UD65 & phenylalanine amonnia lyase \\
\hline & genolin_c7453 & 1.2384 & Q3L7K5 & cell wall apoplastic invertase \\
\hline & genolin_c1532 & 1.2046 & Q6J8W9 & cellulose synthase catalytic subunit \\
\hline & genolin_c7526 & 1.1328 & A4ZYQ7 & secondary wall-associated glycosyltransferase family $8 \mathrm{D}$ \\
\hline & genolin_c26370 & 1.1316 & A6XNE7 & coniferyl alcohol 9-O-methyltransferase \\
\hline & genolin c51183 & 1.0818 & Q6J1A2 & fasciclin-like AGP 2 \\
\hline & genolin_c5939 & 1.0635 & Q93XM0 & xyloglucan endotransglycosylase \\
\hline & genolin_c9188 & 1.0359 & Q5BM98 & secondary cell wall-related glycosyltransferase family 47 \\
\hline & genoin_c59577 & 1.0298 & Q212N3 & xylose synthase \\
\hline & genolin_c629 & 1.0120 & P46484 & caffeic acid o-methyltransferase \\
\hline & genolin_c33660 & -1.6303 & A2TEl8 & xyloglucan endotransglucosylase hydrolase \\
\hline \multirow[t]{23}{*}{ B } & genolin_c31122 & 3.3361 & A5HIJ1 & cysteine protease \\
\hline & genolin_c48400 & 2.5942 & Q84PM1 & puvative germin $\mathrm{E}$ protein \\
\hline & genolin_c59522 & 2.3847 & A8J6X3 & cysteine protease \\
\hline & genolin_c26764 & 2.0526 & QOWT15 & cysteine proteinase \\
\hline & genolin_c7149 & 2.0355 & Q6JVN1 & germin-like protein 3 \\
\hline & genolin_c17050 & 1.7157 & Q1A7T0 & geranylgeranyl diphosphate synthase \\
\hline & genolin_c53940 & 1.4461 & Q42839 & chitinase \\
\hline & genolin_c18213 & 1.4021 & P19825 & major latex protein \\
\hline & genolin_c37826 & 1.2127 & AJ310163 & Nbi-D \\
\hline & genolin_c57840 & 1.2037 & Q6XWA8 & disease resistance protein ler 3 \\
\hline & genolin_c402 & 1.1670 & Q6Y1E9 & cysteine proteinase \\
\hline & genolin_c3610 & 1.1417 & Q6QHU3 & major cherry allergen \\
\hline & genolin_c52667 & 1.1243 & Q51707 & chitinase \\
\hline & genolin_c1342 & 1.1004 & Q6QHU3 & major cherry allergen \\
\hline & genolin_c12178 & -1.0222 & Q0ZPW1 & CXE carboxylesterase \\
\hline & genolin_c16527 & -1.0963 & A0PFJ9 & puvative cysteine protease 8 \\
\hline & genolin_c1047 & -1.1082 & Q9FLV0 & flavanone 3-hydroxylase-like protein \\
\hline & genolin_c26515 & -1.1136 & 065039 & cysteine proteinase \\
\hline & genolin_c13390 & -1.1288 & Q700A7 & pathogen induced protein $2-4$ \\
\hline & genolin_c3363 & -1.1896 & 065039 & cysteine proteinase \\
\hline & genolin_c7458 & -1.3043 & Q9ZQ13 & extracellular lipase \\
\hline & genolin_c5446 & -1.5431 & $\mathrm{~B} 2 \mathrm{Y} 4 \mathrm{~N} 7$ & puvative subtilase family protein \\
\hline & genolin_c505 & -3.0211 & A6YGE4 & hypersensitive-induced response protein \\
\hline
\end{tabular}

Figure 7 Differentially expressed genes in two cultivars, Drakkar and Belinka. Differences concern genes involved in cell wall biosynthesis (A) and response to biotic stimuli (B). Log2ratio were calculated as intensity signal in Drakkar vs. Belinka. Values for up-regulated genes are represented in red and those for down-regulated genes in green colour. 
while 9 genes were up-regulated in Belinka as compared with Drakkar (Figure 7B). Interestingly, 4 of the most up-regulated genes (c31122, c59522, c26764, c402) in Drakkar code for cysteine proteases known to play an important role in programmed cell death (PCD) associated with the hypersensitive response (HR) $[48,49]$. Two other highly up-regulated genes (c7149 and c48400) encode germin-like proteins potentially associated with ROS production and cell-wall cross-linking in defense [50]. One up-regulated gene (Nbi-D c37826) has been previously shown to be involved in flax resistance to rust (Melampsora lini) [51]. In Belinka, the most highly up-regulated gene (c505) as compared to Drakkar correspond to a hypersensitive-induced response protein.

Overall, these results would suggest that our flax microarray platform is capable of detecting biologicallyrelevant differential gene expression between contrasted flax varieties. As such, our microarrays represent a powerful tool for identifying candidate genes potentially associated with quality-related polymorphism and therefore represent a valuable contribution to molecularbased plant improvement programs.

\section{Conclusion}

We have developed a powerful and robust high-density oligo-microarray platform for transcriptomics in flax. High correlations were consistently obtained with technical repetitions on a wide range of different samples and results were cross-validated using an independent method (qRT-PCR). The platform is capable of high discrimination and can provide biologically-useful information on specific gene expression profiles of different flax tissues, and developmental stages. Initial studies also enabled the identification of specifically-expressed cell wall- and defence-related genes in 2 different flax varieties showing contrasting fibre quality and resistance towards a fungal pathogen. These results indicate that our microarray platform can make a useful contribution towards understanding the genetic basis of plant quality in flax.

\section{Methods}

\section{Plant material and tissue collection}

Linum usitatissimum (Barbara an oil-seed cultivar and Hermes a fibre cultivar)[42] plants were grown in a growth chamber (light/night cycles $16 \mathrm{~h}\left(22^{\circ} \mathrm{C}\right) / 8 \mathrm{~h}$ $\left(19^{\circ} \mathrm{C}\right), 50 \%$ humidity and light intensity of $400 \mu \mathrm{E} \mathrm{s}{ }^{-1}$ $\mathrm{m}^{-2}$ ). Individual flowers (Barbara) were tagged at anthesis. The developing seeds of Barbara were collected at 10-15, 20-30 and 40-50 Days After Flowering (DAF), immediately flash-frozen in liquid nitrogen and stored at $-80^{\circ} \mathrm{C}$ until used for experiments. $15 \mathrm{~cm}$-long stem samples were recovered from plants (Hermes) harvested at two different developmental stages: (1) vegetative and (2) green capsule. The outer fibre-bearing tissues were peeled off and inner tissues (xylem) cut into short fragments before both tissues were frozen in liquid nitrogen. Leave samples (Hermes) were collected at vegetative stage, immediately frozen in liquid nitrogen and stored at $-80^{\circ} \mathrm{C}$. For root samples, plants (Hermes) were grown in a mixture of sand and vermiculites in a growth chamber (light/night cycles $16 \mathrm{~h}\left(22^{\circ} \mathrm{C}\right) / 8 \mathrm{~h}\left(19^{\circ} \mathrm{C}\right), 50 \%$ humidity and light intensity of $150 \mu \mathrm{E} \mathrm{s}^{-1} \mathrm{~m}^{-2}$ ) for 10 days. Roots were rinsed in cold water $\left(4^{\circ} \mathrm{C}\right)$ and the extremity of each root was cut off, frozen in liquid nitrogen, and stored at $-80^{\circ} \mathrm{C}$.

\section{RNA extraction}

Total RNA was isolated from the collected tissues. $100 \mathrm{mg}$ of frozen seed samples were ground in liquid nitrogen and polyphenols and polysaccharides were precipitated [52] prior to RNA extraction by hot phenol, modified after Verwoerd et al. [53]. $100 \mathrm{mg}$ of frozen stem/root/leaf tissues were ground in liquid nitrogen using the Trizol method (Invitrogen, Carlsbad, CA). Total RNAs were purified using the RNeasy Plant kit (Qiagen) according to the manufacturer's instructions. The genomic DNA was eliminated after treatment with Dnase I for $20 \mathrm{~min}$ at $37^{\circ} \mathrm{C}$ using the DNA-free kit (Ambion, Austin, TX, USA). RNA was checked for purity and degradation by capillary electrophoresis using the Bio-Analyzer Experion (Bio-Rad; RNA Standard Sens kit; RNA StdSens chips). RNA concentration was also determined by spectrometry and only RNAs with an OD260:OD280 ratio of $>1.8$ and no discernable degradation were used in PCR-based experiments.

\section{Sequencing and Bioinformatics}

454 GS FLX technology was used to sequence 9 different RNA samples extracted from 2 distinct flax genotypes and different tissues/developmental stages (Table 1). Individual libraries were prepared for each sample using the MID bar-coding system from Roche. Four separate half GS FLX runs were performed (2 total runs) on 4 cDNA library pools: 1) leaf and root; 2) 3 seed developmental stages; 3) Internal/external stem samples, vegetative stage; 4) internal/external stem samples, green capsule stage. Raw data was generated as Sff files. The Sff_extract tool http://bioinf.comav.upv.es/sff_extract/ index.html was used to extract reads, qualities and A and $B$ adaptor positions for each sample. A specific search for SMART forward and reverse primers was performed on all reads using cross_match utility.

\section{Assembly and annotation}

Reads from each genotype were identified, and a de novo assembly of all reads/samples was performed using the 
MIRA tool (development version number $2.9 .29 \times 4$ ). Parameters used were the default ones plus: -job = denovo, est, normal, 454 -GE: $n$ ot $=8$-GE:kcim $=$ on LR:mxti $=$ yes $-\mathrm{SB}: 1 \mathrm{sd}=$ on $-\mathrm{CL}: \mathrm{mbc}=$ on. By default, reads smaller than $40 \mathrm{bp}$ are excluded by MIRA. Reads and contigs were then stored in an EST2uni database for data and annotation management.

\section{Microarray design and oligo synthesis}

A total of 384,168 oligonucleotides (25-mers long) were designed and used to construct high-density flax microarrays based on the Nimblegen $385 \mathrm{~K}$ design format (Nimblegen Systems, Inc., Madison, WI, USA). This design enabled an elevated number (8) of distinct oligos to be used for each of the 48,021 contigs selected from the overall total of 59,000 contigs obtained by assembling the GS FLX sequences. Technical specifications and design files of this new platform for high-throughput analysis of gene expression in flax are publicly available on the GEO website under accession number GPL10419.

\section{cDNA synthesis, labeling and hybridization}

Double-stranded cDNA (ds-cDNA) was synthesized from $10 \mu \mathrm{g}$ of total RNA using an Invitrogen SuperScript dscDNA synthesis kit in the presence of $250 \mathrm{ng}$ random hexamer primers. ds-cDNA was cleaned and labeled in accordance with the Nimblegen Gene Expression Analysis protocol (Nimblegen Systems, Inc., Madison, WI, USA). Briefly, ds-cDNA was incubated with $4 \mu \mathrm{g}$ RNase $\mathrm{A}$ (Promega) at $37^{\circ} \mathrm{C}$ for $10 \mathrm{~min}$ and cleaned using phenol:chloroform:isoamyl alcohol, followed by ice-cold absolute ethanol precipitation. For Cy3 labeling of cDNA, the Nimblegen One-Color DNA labeling kit was used according to the manufacturer's guideline detailed in the Gene Expression Analysis protocol (Nimblegen Systems, Inc., Madison, WI, USA). One $\mu \mathrm{g}$ ds-cDNA was incubated for $10 \mathrm{~min}$ at $98^{\circ} \mathrm{C}$ with $2 \mathrm{OD}$ of Cy3-9mer primer. Then, $100 \mathrm{pmol}$ of deoxynucleoside triphosphates and $100 \mathrm{U}$ of the Klenow fragment (New England Biolabs, Ipswich, MA, USA) were added and the mix incubated at $37^{\circ} \mathrm{C}$ for $2 \mathrm{~h} 30$. The reaction was stopped by adding 0.1 volume of $0.5 \mathrm{M}$ EDTA, and the labeled ds-cDNA was purified by isopropanol/ethanol precipitation. Microarrays were hybridized at $38^{\circ} \mathrm{C}$ during 16 to $18 \mathrm{~h}$ with $6 \mu \mathrm{g}$ of Cy3 labelled ds-cDNA in Nimblegen hybridization buffer/hybridization component $\mathrm{A}$ in a hybridization chamber (Hybridization System - Nimblegen Systems, Inc., Madison, WI, USA). Following hybridization, washing was performed using the Nimblegen Wash Buffer kit (Nimblegen Systems, Inc., Madison, WI, USA).

\section{Data Analysis}

Slides were scanned at $5 \mu \mathrm{m} /$ pixel resolution using an Axon GenePix 4000 B scanner (Molecular Devices
Corporation, Sunnyvale, CA, USA) piloted by GenePix Pro 6.0 software (Axon). Scanned images (TIFF format) were then imported into NimbleScan software (Nimblegen Systems, Inc., Madison, WI, USA) for grid alignment and expression data analyses. Expression data were normalized through quantile normalization [54] and the Robust Multichip Average (RMA) algorithm [55] included in the NimbleScan software. Identification of genes displaying a change in expression over repetitions was accomplished with a script utilizing library functions in $\mathrm{R}$ with a false discovery rate (FDR) of less than 5\%. The SAM [56] was used to identify differentially expressed genes over different conditions and $\log 2$ (ratio) $\geq 1$ and $\leq-1$ were used for filtering gene expression profiles. Analysis was completed with the PCA module of the J-express program [57]. Functional annotation of differentially-expressed genes was based on Gene Ontology http://www.geneontology.org/. All the microarray data have been submitted to the Gene Expression Omnibus (GEO) database http://www.ncbi. nlm.nih.gov/geo with the accession number GSE21868.

\section{Quantitative reverse transcriptase-PCR (qRT-PCR) analysis cDNA Synthesis}

$5 \mu \mathrm{g}$ aliquots of total RNA were treated with DNaseI using a TURBO DNA-free Kit (Ambion) according to the manufacturer's instructions, then first-strand cDNA was synthesized using $\mathrm{M}-\mathrm{MuLV}$ RNase $\mathrm{H}^{-}$reverse transcriptase (Finnzymes) with $2.5 \mu \mathrm{g}$ of random hexamers and $500 \mathrm{ng}$ of oligo(dT)12 according to the manufacturer's instructions. The reaction was stopped by incubation at $70^{\circ} \mathrm{C}$ for $10 \mathrm{~min}$, and the reaction mixture treated with RNaseH (BioLabs) according to the manufacturer's instructions before dilution with $600 \mu \mathrm{L}$ of sterile de-ionized water.

\section{qRT-PCR Experiment Design}

Transcript levels were assessed by qRT-PCR, in assays with triplicate reaction mixtures (final volume, $20 \mu \mathrm{L}$ ) containing $5 \mu \mathrm{L}$ of cDNA, $0.5 \mu \mathrm{M}$ of both forward and reverse primers, and $1 \mathrm{X}$ DyNamo Capillary SYBR Green qRTPCR mix (Finnzymes). qRT-PCR experiments used a balanced randomized block design, as recently advised [58]. A LightCycler (Roche) was used to acquire the CT values for each sample. The following standard protocol was applied for all amplifications: $10 \mathrm{~min}$ at $95^{\circ} \mathrm{C}$, followed by 45 cycles of $10 \mathrm{~s}$ at $95^{\circ} \mathrm{C}, 15 \mathrm{~s}$ at $60^{\circ} \mathrm{C}$, and $15 \mathrm{~s}$ at $72^{\circ} \mathrm{C}$. A melting curve analysis was added to each PCR program and the size of PCR products was assessed by electrophoresis in agarose gels. The primer sequences used for all target genes are presented in Additional file 5.

Relative standard curves describing the PCR efficiencies (E) for each primer pair were generated for each amplicon according to Larionov et al. [59]. Normalization of qRT-PCR was performed using reference genes 
(R) according to Gutierrez et al. [60]. Twelve genes (Additional file 5) were chosen for their stability across the set of microarray experiments previously shown in this paper. Their expression was assessed by qRT-PCR, and they were ranked according to their stability of expression using geNorm software [61]. The_c3168 (lcl| genolin_c3168 $628 \mathrm{nt}$ ) and c10916 (lcl|genolin_c10916 $813 \mathrm{nt})$ genes were the most stably expressed ones among the 12 tested and, thus, were used to normalize the qRT-PCR data. The normalized expression patterns obtained using both reference genes were similar, so only the data normalized with $c 10916$ (highly similar to a Dehydrodolichyl diphosphate synthase 6 of Arabidopsis thaliana) are shown in this article. Gene expression was calculated using $C T$ and $E$ values with the formula, $\mathrm{E}_{\mathrm{T}}{ }^{\left({ }^{C T}\right.}{ }_{\text {tissueA }}{ }^{-\mathrm{CT}}{ }_{\text {tissueB }}{ }^{1} / \mathrm{E}_{\mathrm{R}}\left({ }^{\left({ }^{(C T}\right.}{ }_{\text {tissueA }}{ }^{-{ }^{-C T}}{ }_{\text {tissueB }}\right)$, where $(\mathrm{T})$ is the target gene and $(\mathrm{R})$ the reference gene, (tissueA) is related to cDNA from the tissue showing the lowest expression and (tissueB) from the tissue showing the highest expression. All qRT-PCR results represent means as calculated from the three technical replicates [58].

\section{Additional material}

\begin{abstract}
Additional file 1: Analyses of differential gene expression between stem inner tissues and stem outer tissues sampled at vegetative and green capsule stages. Lists of differentially expressed genes and GO analyses (biological processes) for i) stem inner vegetative (SIV) vs stem outer vegetative (SOV), ii) stem inner green capsule (SIGC) vs stem outer green capsule (SOGC), iii) stem inner vegetative (SIV) vs stem inner green capsule (SIGC), iv) stem outer vegetative (SOV) vs stem outer green capsule (SOGC).
\end{abstract}

Additional file 2: Analyses of differential gene expression (selected functional groups) between stem inner tissues and stem outer tissues sampled at vegetative and green capsule stages. Lists of differentially expressed genes (selected functional groups only) for i) stem inner vegetative (SIV) vs stem outer vegetative (SOV), ii) stem inner green capsule (SIGC) vs stem outer green capsule (SOGC), iii) stem inner vegetative (SIV) vs stem inner green capsule (SIGC), iv) stem outer vegetative (SOV) vs stem outer green capsule (SOGC). Lists of differentially expressed genes and $\mathrm{GO}$ analyses (biological processes) for i) stem inner vegetative (SIV) vs stem outer vegetative (SOV), ii) stem inner green capsule (SIGC) vs stem outer green capsule (SOGC), iii) stem inner vegetative (SIV) vs stem inner green capsule (SIGC), iv) stem outer vegetative (SOV) vs stem outer green capsule (SOGC).

Additional file 3: Differentially expressed genes between Drakkar and Belinka flax cultivars. List of differentially expressed genes between Drakkar and Belinka flax cultivars. Values for up-regulated genes are represented in red and those for down-regulated genes in green colour.

Additional file 4: Number of differentially expressed genes between Drakkar and Belinka flax cultivars represented as GO biological process. Drakkar specifically expressed genes are represented as dark columns and those of Belinka as clear columns.

Additional file 5: Primer sequences used in qRT-PCR analyses. Sequences of primers used for quantifying target genes by qRT-PCR (Table 1) and Sequences of primers for putative reference genes tested by geNorm (Table 2).

\section{Acknowledgements}

This work was financially supported by ANR (ANR-06-GPAL-017: Genolin project) and by the Pôle of competitivity Industry and Agro-Ressources. SF et YN gratefully acknowledge the financial support of the French national research agency (ANR: Genolin project). SF also acknowledges the financial support of the Nord Pas-de-Calais Region (Plant Teq project 4). BT thanks the EU for the financial contribution towards equipments acquired in the operational regional competitivity program.

\section{Author details}

'Université Lille Nord de France, Lille 1 UMR INRA 1281, SADV, F- 59650 Villeneuve d'Ascq cedex, France. ${ }^{2}$ EA 3900-BioPI, UFR des Sciences, UPJV, 33 rue Saint Leu, 80039 Amiens cedex, France. ${ }^{3}$ BIOGEMMA, Z.I. du Brezet, 8 rue des Frères Lumières, 63028 Clermont-Ferrand cedex 2, France. ${ }^{4}$ BIOGEMMA, domaine de Sandreau, Chemin de Panedautes, 31700 Mondonville, France. ${ }^{5}$ Institut Technique de Lin, 27170 Ecardenville La Campagne, France. ${ }^{6}$ CRRBM, UFR des Sciences, UPJV, 33 rue Saint Leu, 80039 Amiens cedex, France. "UMR- INRA, UMR614, URCA, FARE, 2 Esplanade R. Garros, CREA, BP 224, 51686 Reims, France. ${ }^{8}$ Laboulet Semences, 80270 Airaines, France. 'LINEA, 20 Avenue Saget, 60210 Grandvilliers, France. ${ }^{10}$ UMR CNRS 6022 , GEC, Université de Technologie de Compiègne, BP 20529, 60205 Compiègne cedex, France.

\section{Authors' contributions}

BT conceived and designed the project. BT and RT grew flax plants and provided samples. BT and BC characterized the biological materials. NR and JD managed the 454 sequencing, data assembly, conceived and constructed the database and oligo design. AL, SF and OW performed microarrays experiments. LG validated array data with qRT-PCR. SH managed manuscript preparation. All listed authors edited the manuscript. All authors read and approved the final manuscript.

Received: 29 July 2010 Accepted: 21 October 2010

Published: 21 October 2010

\section{References}

1. Deyholos MK: Bast fiber of flax (Linum usitatissimum L.): Biological foundations of its ancient and modern uses. Israel Journal of Plant Sciences 2006, 54(4):273-280.

2. Vaisey-Genser M, Morris DH: History of the cultivation of flaxseed. In Flax, the genus Linum. Edited by: Muir AD, Wescott ND. CRC Press, Taylor 2003:1-21.

3. Baley C, Perrot Y, Busnel F, Guezenoc H, Davies P: Transverse tensile behaviour of unidirectional plies reinforced with flax fibres. Materials letters 2006, 60(24):2984-2987.

4. Kymäläinen HR, Sjöberga AM: Flax and hemp as raw materials for thermal insulations. Building and Environment 2008, 43:1261-1269.

5. Farmer C, Petit HV, Weiler H, Capuco AV: Effects of dietary supplementation with flax during prepuberty on fatty acid profile, mammogenesis, and bone resorption in gilts. Journal of Animal Science 2007, 85(7):1675-1686.

6. Dodin S, Cunnane SC, Masse B, Lemay A, Jacques H, Asselin G, TremblayMercier J, Marc I, Lamarche B, Legare F, et al: Flaxseed on cardiovascular disease markers in healthy menopausal women: a randomized, doubleblind, placebo-controlled trial. Nutrition 2008, 24(1):23-30.

7. Felmlee MA, Woo G, Simko E, Krol ES, Muir AD, Alcorn J: Effects of the flaxseed lignans secoisolariciresinol diglucoside and its aglycone on serum and hepatic lipids in hyperlipidaemic rats. The British Journal of Nutrition 2009, 102(3):361-369.

8. Chen J, Soucek MD, Simonsick WJ, Celikay RW: Synthesis and photopolymerization of norbornyl epoxidized linseed oil. Polymer 2002, 43:5379-5389.

9. Hall C, Tulbek MC, Xu Y: Flaxseed. Adv Food Nutr Res 2006, 51:1-97.

10. Day A, Neutelings G, Nolin F, Grec S, Habrant A, Cronier D, Maher B, Rolando C, David H, Chabbert B, et al: Caffeoyl coenzyme A Omethyltransferase down-regulation is associated with modifications in lignin and cell-wall architecture in flax secondary xylem. Plant Physiology \& Biochemistry 2009, 47(1):9-19. 
11. Gutierrez L, Conejero G, Castelain M, Guenin S, Verdeil JL, Thomasset B, Van Wuytswinkel $\mathrm{O}$ : Identification of new gene expression regulators specifically expressed during plant seed maturation. Journal of Experimental Botany 2006, 57(9):1919-1932.

12. Rao S, Abdel-Reheem M, Bhella R, McCracken C, Hildebrand D: Characteristics of high alpha-linolenic acid accumulation in seed oils. Lipids 2008, 43(8):749-755.

13. Bennett MD, Leitch IJ: Plant DNA C-values database (release 3.0). 2004 [http://www.rbgkew.org.uk/cval/homepage.html]

14. Day A, Addi M, Kim W, David H, Bert F, Mesnage P, Rolando C, Chabbert B, Neutelings G, Hawkins S: ESTs from the fibre-bearing stem tissues of flax (Linum usitatissimum L.): expression analyses of sequences related to cell wall development. Plant Biology 2005, 7(1):23-32.

15. De Pauw MA, Vidmar JJ, Collins J, Bennett RA, Deyholos MK: Microarray analysis of bast fibre producing tissues of Cannabis sativa identifies transcripts associated with conserved and specialised processes of secondary wall development. Functional Plant Biology 2007, 34(8):737-749.

16. Hotte NS, Deyholos MK: A flax fibre proteome: identification of proteins enriched in bast fibres. BMC Plant Biology 2008, 8:52.

17. Roach MJ, Deyholos MK: Microarray analysis of flax (Linum usitatissimum L.) stems identifies transcripts enriched in fibre-bearing phloem tissues. Molecular Genetics \& Genomics 2007, 278(2):149-165.

18. Roach MJ, Deyholos MK: Microarray analysis of developing flax hypocotyls identifies novel transcripts correlated with specific stages of phloem fibre differentiation. Annals of Botany 2008, 102(3):317-330.

19. Moreau Y, Aerts S, De Moor B, De Strooper B, Dabrowski M: Comparison and meta-analysis of microarray data: from the bench to the computer desk. Trends in Genetics 2003, 19(10):570-577.

20. Nimgaonkar A, Sanoudou D, Butte AJ, Haslett JN, Kunkel LM, Beggs AH, Kohane IS: Reproducibility of gene expression across generations of Affymetrix microarrays. BMC Bioinformatics 2003, 4:27.

21. Hardiman G: Microarray platforms-comparisons and contrasts. Pharmacogenomics 2004, 5(5):487-502.

22. Wang Y, Barbacioru C, Hyland F, Xiao W, Hunkapiller KL, Blake J, Chan F, Gonzalez C, Zhang L, Samaha RR: Large scale real-time PCR validation on gene expression measurements from two commercial longoligonucleotide microarrays. BMC genomics 2006, 7:59.

23. Buick R: When did oxygenic photosynthesis evolve? Philosophical Transactions of the Royal Society of London B Biological Science 2008, 363(1504):2731-2743

24. Campbell NA, Williamson B, Heyden RJ: Biology: Exploring Life. Boston, Masschussets: Pearson Prentice Hall 2006.

25. Douglas SE: Plastid evolution: origins, diversity, trends. Current Opinion in Genetics \& Development 1998, 8(6):655-661.

26. Gould SB, Waller RF, McFadden Gl: Plastid evolution. Annual Review of Plant Biology 2008, 59:491-517.

27. Nealson KH, Conrad PG: Life: past, present and future. Philosophical Transactions of the Royal Society of London B Biological Science 1999, 354(1392):1923-1939.

28. Raven PH, Evert RF, Eichhorn SE: Biology of Plants, 7th Edition. New York: W.H. Freeman and Company Publishers 2005.

29. Reyes-Prieto A, Weber AP, Bhattacharya D: The origin and establishment of the plastid in algae and plants. Annual Review of Genetics 2007, 41:147-168.

30. Rodriguez-Ezpeleta N, Brinkmann H, Burey SC, Roure B, Burger G, Loffelhardt W, Bohnert HJ, Philippe H, Lang BF: Monophyly of primary photosynthetic eukaryotes: green plants, red algae, and glaucophytes. Current Biology 2005, 15(14):1325-1330.

31. Smith AL: Oxford dictionary of biochemistry and molecular biology. Oxford: Oxford University Press 1997.

32. Bengough AG, Bransby MF, Hans J, McKenna SJ, Roberts TJ, Valentine TA: Root responses to soil physical conditions; growth dynamics from field to cell. Journal of Experimental Botany 2006, 57(2):437-447.

33. Okubara PA, Paulitz TC: Root defense responses to fungal pathogens: A molecular perspective. Plant and Soil 2005, 274(1-2):215-226.

34. Day A, Ruel K, Neutelings G, Cronier D, David H, Hawkins S, Chabbert B: Lignification in the flax stem: evidence for an unusual lignin in bast fibers. Planta 2005, 222(2):234-245.
35. Dupree P: Plant embryogenesis: cell division forms a pattern. Current Biology 1996, 6(6):683-685.

36. Troufflard S, Roscher A, Thomasset B, Barbotin JN, Rawsthorne S, Portais JC: In vivo $13 \mathrm{C}$ NMR determines metabolic fluxes and steady state in linseed embryos. Phytochemistry 2007, 68(16-18):2341-2350.

37. Mellerowicz EJ, Sundberg B: Wood cell walls: biosynthesis, developmental dynamics and their implications for wood properties. Current Opinion in Plant Biology 2008, 11(3):293-300.

38. Larfarguette F, Leplé JC, Déjardin A, Laurens F, Costa G, LesageDescauses MC, Pilate: Poplar genes encoding fasciclin-like arabinogalactan proteins are highly expressed in tension wood. New Phytol 2004, 164:107-121

39. Yeats $\mathrm{TH}$, Rose JKC: The biochemistry and biology of extracellular plant lipid-transfer proteins (LTPs). Protein Sci 2008, 17:191-198.

40. Gorshkova TA, Sal'nikov W, Chemikosova SB, Ageeva MV, Pavlencheva NV, van Dam JEG: The snap point: a transition point in Linum usitatissimum bast fiber development, Ind. Crops and Prod 2003, 18:213-221.

41. His I, Andème-Onzighi C, Morvan C, Driouich A: Microscopic studies on mature flax fibers embedded in LR White: immunogold localization of cell wall matrix polysccharides, 2001. J Histochem and Cytochem 2001, 49(12):1525-1535.

42. Vromans J: Molecular genetic studies in flax (Linum usitatissimum L.). pHD thesis Wageningen University, The Netherlands 2006.

43. Morvan C, Andème-Onzighi C, Girault R, Himmelsbach DS, Driouich A, Akin DE: Building flax fibres: more than one brick in the walls. Plant Physiology and Biochemistry 2003, 41(11-12):935-944.

44. Tang GQ, Luscher M, Sturm A: Antisense repression of vacuolar and cell wall invertase in transgenic carrot alters early plant development and sucrose partitioning. Plant Cell 1999, 11(2):177-189.

45. Gorshkova T, Gurjanov O, Mikshina P, Ibragimova N, Mokshina N, Salnikov V, Ageeva M, Amenitskii S, Chernova T, Chemikosova S: Specific type of secondary cell wall formed by plant fibers. Russian Journal of Plant Physiology 2010, 57(3):328-341.

46. Hobson N, Roach M, Deyholos M: Gene expression in tension wood and bast fibres. Russian Journal of Plant Physiology 2010, 57(3):321-327.

47. Kaku T, Serada S, Baba Ki, Tanaka F, Hayashi T: Proteomic analysis of the Glayer in poplar tension wood. Journal of Wood Science 2009, 55(4):250-257.

48. Woltering EJ: Death proteases: alive and kicking. Trends in Plant Science 2010, 15(4):185-188.

49. Zhang L, Xu Q, Xing D, Gao C, Xiong H: Real-time detection of caspase-3like protease activation in vivo using fluorescence resonance energy transfer during plant programmed cell death induced by ultraviolet $\mathrm{C}$ overexposure. Plant Physiology 2009, 150(4):1773-1783.

50. Manosalva PM, Davidson RM, Liu B, Zhu X, Hulbert SH, Leung H, Leach JE: A germin-like protein gene family functions as a complex quantitative trait locus conferring broad-spectrum disease resistance in rice. Plant Physiology 2009, 149(1):286-296.

51. Islam R, Sheperd KW, Mayo GME: Effect of genotype and temperature on the expression of $L$ genes in flax conferring resistance to rust. Physiology and Molecular Plant Pathology 1989, 35(2):141-150.

52. Gehrig HH, Winter K, Cushman JC, Borland AM, Taybi T: An improved RNA isolation method for succulent plant species rich in polyphenols and polysaccharides. Plant Molecular Biology Report 2000, 18:369-376.

53. Verwoerd TC, Dekker BM, Hoekema A: A small-scale procedure for the rapid isolation of plant RNAs. Nucleic Acids Research 1989, 17(6):2362.

54. Bolstad BM, Irizarry RA, Astrand M, Speed TP: A comparison of normalization methods for high density oligonucleotide array data based on variance and bias. Bioinformatics 2003, 19(2):185-193.

55. Irizarry RA, Hobbs B, Collin F, Beazer-Barclay YD, Antonellis KJ, Scherf U, Speed TP: Exploration, normalization, and summaries of high density oligonucleotide array probe level data. Biostatistics 2003, 4(2):249-264.

56. Tusher VG, Tibshirani R, Chu G: Significance analysis of microarrays applied to the ionizing radiation response. Proceedings of the National Academy of Sciences of the USA 2001, 98(9):5116-5121.

57. Dysvik B, Jonassen I: J-Express: exploring gene expression data using Java. Bioinformatics 2001, 17(4):369-370.

58. Rieu I, Powers SJ: Real-time quantitative RT-PCR: design, calculations, and statistics. Plant Cell 2009, 21(4):1031-1033. 
59. Larionov A, Krause A, Miller W: A standard curve based method for relative real time PCR data processing. BMC Bioinformatics 2005, 6:62.

60. Gutierrez L, Mauriat M, Pelloux J, Bellini C, Van Wuytswinkel O: Towards a systematic validation of references in real-time rt-PCR. Plant Cell 2008, 20(7):1734-1735.

61. Vandesompele J, De Preter K, Pattyn F, Poppe B, Van Roy N, De Paepe A, Speleman F: Accurate normalization of real-time quantitative RT-PCR data by geometric averaging of multiple internal control genes. Genome Biology 2002, 3(7):RESEARCH0034.

doi:10.1186/1471-2164-11-592

Cite this article as: Fenart et al:: Development and validation of a flax (Linum usitatissimum L.) gene expression oligo microarray. BMC

Genomics 2010 11:592.

Submit your next manuscript to BioMed Central and take full advantage of:

- Convenient online submission

- Thorough peer review

- No space constraints or color figure charges

- Immediate publication on acceptance

- Inclusion in PubMed, CAS, Scopus and Google Scholar

- Research which is freely available for redistribution

Submit your manuscript at www.biomedcentral.com/submit
C Biomed Central 